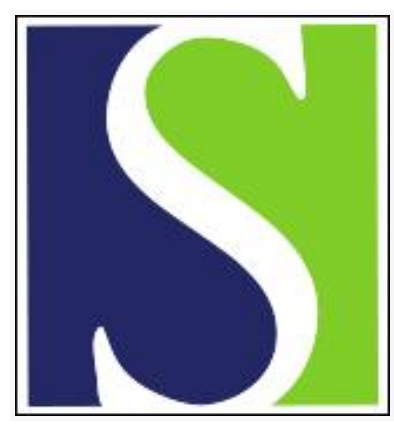

Scand J Work Environ Health 2004;30(6):445-449

https://doi.org/10.5271/sjweh.833

Issue date: Dec 2004

\title{
Exposure to ozone gases in pulp mills and the onset of rhinitis
} by Hoffman CD, Henneberger PK, Olin A-C, Mehta A, Torén K

Affiliation: Division of Respiratory Disease Studies, National Institute for Occupational Safety and Health, 1095 Willowdale Road, Morgantown, WV 26505, USA. cdh@cdc.gov]

Refers to the following text of the Journal: 2002;28(2):117-123

Key terms: bleachery worker; exposure; ozone; ozone gas; pulp mill; rhinitis

This article in PubMed: www.ncbi.nlm.nih.gov/pubmed/15633595 


\title{
Exposure to ozone gases in pulp mills and the onset of rhinitis
}

\author{
by Christopher D Hoffman, MS, ${ }^{1}$ Paul K Henneberger, ScD, ${ }^{1}$ Anna-Carin Olin, MD, ${ }^{2}$ Amar Mehta, MPH, ${ }^{1}$ \\ Kjell Torén, $M D^{2}$
}

Hoffman CD, Henneberger PK, Olin A-C, Mehta A, Torén K. Exposure to ozone gases in pulp mills and the onset of rhinitis. Scand J Work Environ Health 2004;30(6):445-449.

\begin{abstract}
Objective Rhinitis is a common upper respiratory disease influenced by both genetic and environmental factors. It is also accepted that allergic rhinitis may precede asthma, a disease with more serious consequences. The purpose of this study was to determine whether the risk of noninfectious rhinitis is increased after accidental gassings with ozone among bleachery workers in two pulp mills.

Methods Bleachery workers $(\mathrm{N}=120)$ from two Swedish pulp mills using ozone as their bleaching agent were compared with control workers $(\mathrm{N}=80)$ not exposed to ozone in two adjacent paper mills. All of the participants were mailed a respiratory questionnaire that included items about asthma, noninfectious rhinitis, self-reported gassings, and smoking. Hazard ratios (HR) were calculated with proportional hazards regression models.

Results The bleachery workers who reported gassings from ozone were found to be at increased risk of noninfectious rhinitis [HR 3.4, 95\% confidence interval (95\% CI) 1.3-8.7] when compared with control workers. Bleachery workers without self-reported ozone gassings were not at increased risk (HR 0.9, 95\% CI 0.3-2.4).

Conclusion Acute exposure to high levels of ozone increases the risk of noninfectious rhinitis. This finding supports the view that peak exposures to irritants should be prevented in pulp mills.
\end{abstract}

Key terms worker, bleachery; ozone.

Pulp mill workers, especially those engaged in the bleachery process, are potentially exposed to many irritant gases, including chlorine, chlorine dioxide $\left(\mathrm{ClO}_{2}\right)$, sulfur dioxide $\left(\mathrm{SO}_{2}\right)$, and hydrogen sulfide. Ozone has been used as a replacement for chlorine and $\mathrm{ClO}_{2}$ in the pulp bleaching process at mills in Sweden since 1992 (1). Workers are sometimes exposed to these gases at high levels due to accidental leakage. Several studies have shown an increase in lower respiratory symptoms due to these accidental gassings (2-5). In addition, Olin et al (4) reported an increase in exhaled nitric oxide, which indicates possible respiratory inflammation, after exposure to ozone gassings. Many studies have also shown a link between exposure to ambient levels of ozone and asthma (6-9).

Rhinitis is a common health problem in the United States, affecting 40 to 50 million adults, and is three times more prevalent than asthma in certain occupational settings $(10,11)$. Rhinitis has previously been defined as the presence of nasal symptoms such as nasal congestion, secretion, itching, and sneezing (12). Questions based on these symptoms have been used in several studies to define rhinitis (13-15). Rhinitis unrelated to infection is not considered as medically serious a disease as asthma; however, Bousquet et al (16) found health-related quality of life to be worse among those with rhinitis than among those with asthma (16). Recent studies have also suggested that rhinitis is an independent risk factor for adult-onset asthma without atopy (17-19).

Because rhinitis is considered a less serious disease, the epidemiology of rhinitis due to occupational exposures has not been investigated widely. Etiologic agents for occupational rhinitis, like those for occupational asthma, can be classified into high- or low-weight-molecular agents. (20) A recent literature review on occupational rhinitis found several occupations that may increase the risk for rhinitis, including laboratory animal

1 Division of Respiratory Disease Studies, National Institute for Occupational Safety and Health, Centers for Disease Control and Prevention, Morgantown, West Virginia, United States.

2 Department of Occupational and Environmental Medicine, Department of Respiratory Medicine and Allergology, Sahlgrenska University Hospital, Göteborg, Sweden.

Reprint requests to: Dr Paul Henneberger, Division of Respiratory Disease Studies, National Institute for Occupational Safety and Health, 1095 Willowdale Road, Morgantown, WV 26505, USA. [E-mail: pkh0@cdc.gov] 
handlers, wool textile mill workers, bakers, aquarists, fish-food factory workers, workers exposed to anhydrides, platinum refinery workers, and workers exposed to reactive dyes (20). Occupational rhinitis may also result from upper-airway exposure to irritants $(20,21)$. With respect to exposures to irritant gases in pulp mills, accidental exposure to chlorine gas has been linked to an increased risk for rhinitis among pulp mill workers (21).

In a recent study, increased amounts of ozone and $\mathrm{SO}_{2}$ in ambient air were shown to be related to an increase in health care visits for allergic rhinitis (22). A recent literature review of the effects of pollutants on rhinitis highlighted studies that indicate that ozone induces greater nasal inflammation in atopic persons than in nonatopic persons (23). Furthermore, ozone can enhance responses to allergens through mediation by immunoglobulin E, and chronic exposure to ozone has been linked to DNA (deoxyribonucleic acid) changes in the nasal airway. (23)

The aim of this study was to determine whether occupational exposure to ozone and other gases (ie, $\mathrm{ClO}_{2}$ and $\mathrm{SO}_{2}$ ) through accidental gassings is associated with noninfectious rhinitis.

\section{Study population and methods}

In 1996 and 1997, all process, maintenance, and laboratory workers potentially exposed to ozone in the bleaching departments of two sulfate pulp mills were asked to participate in the study $(\mathrm{N}=139)$. Ten workers refused to participate, leaving 129 (93\%) bleachery workers potentially exposed to ozone who participated. All of the process workers, exposed to neither ozone nor $\mathrm{ClO}_{2}$, from two nearby paper mills were asked to participate as the control group $(\mathrm{N}=93)$. Process workers in paper mills are primarily exposed to paper dust, but they may also be exposed to paper additives and slimicides. (24) Thirteen refused to participate, leaving 80 $(86 \%)$ unexposed paper mill worker participants. Since the two sulfate pulp mills began using ozone as their bleaching agent in 1992 and 1993, all the participants who reported an onset of rhinitis prior to 1992 were excluded from the current analysis. Follow-up began for all the workers in 1992 and continued until either 1996 or the year of reported onset of rhinitis, whichever came first. Additional information on selection of the participants can be found elsewhere $(4,5)$.

\section{Outcome assessment}

All of the participants were mailed a respiratory questionnaire, as previously described (4). Noninfectious rhinitis has previously been defined as a positive response to the question: "Since the age of 15, have you ever had a problem with blocked nose and/or attacks of sneezing or runny nose apart from a cold?" $(25,26)$. As we were interested in adult-onset rhinitis, the analysis was restricted to only the symptoms occurring after the age of 15 years.

Blood samples were obtained from all the participants, the sera being analyzed using Phadiatop ${ }^{\circledR}$ commercial kits in accordance with the manufacturer's instructions (Pharmacia Upjohn Diagnostics, Uppsala, Sweden). Atopy in an adult was defined as a positive Phadiatop ${ }^{\circledR}$ test, whereby class 0 was regarded as nonatopic and class 1 as atopic. (27) Atopy in a child was defined as a positive response to the following question, "Did you ever have any form of allergy as a child (ie, hay fever, asthma or eczema)?"

\section{Exposure assessment}

Chlorine or $\mathrm{ClO}_{2}$ use as a bleaching agent in each of the two sulfate pulp mills (mills A \& B) started in the $1950 \mathrm{~s}$, but these agents were replaced with ozone in 1992 at mill A and in 1993 at mill B. Workers were still exposed to other irritant gases after the introduction of ozone. $\mathrm{SO}_{2}$ and $\mathrm{ClO}_{2}$ are still used in mill $\mathrm{B}$, while mill A ended the use of these compounds in 1995.

Under normal conditions, the concentration of ozone in a pulp mill is low $[<40$ parts per billion (ppb)], but the concentration of ozone can briefly be very high (>10 $000 \mathrm{ppb}$ ) during accidental gassings (4). In 1995 and 1996, stationary measurements of ambient ozone concentrations were conducted in mills A and B for 366 days in the ozonator and mixing rooms, two critical areas for high ozone exposure, and the measurements showed that ozone levels exceeded $900 \mathrm{ppb}$ on 6 of the 366 days. (4) However, the stationary measurements were probably not representative of personal exposures during gassing events. Consequently, responses to items in the respiratory questionnaire were used to determine self-reported personal exposure to irritant gassings. Any irritant gassing exposure was defined by a reported exposure to $\mathrm{ClO}_{2}, \mathrm{SO}_{2}$, or ozone resulting in coughing, wheezing, breathlessness, or pain in the thorax. Ozonegassing exposure was defined by a reported exposure to ozone resulting in coughing, wheezing, breathlessness, or pain in the thorax. These definitions have been used by others $(2,3)$.

\section{Statistical analysis}

We performed chi-square tests for univariate analyses using SAS version 8 (28). Potential confounders and effect modifiers included both time-dependent variables (eg, age and smoking) and variables that did not vary 
during the follow-up (eg, atopy and gender). We examined the potential for effect modification by testing the homogeneity of the odds ratios among the exposed and unexposed groups stratified by the covariate. We investigated the potential for confounding by comparing the Mantel-Haenszel odds ratio, adjusted for the potential confounder, to the crude odds ratio. Rhinitis was modeled with proportional hazards regression using the EFRON procedure to handle ties among time-dependent variables (29). Both forward and backward stepwise procedures were used to fit the proportional hazards models. Any covariate with $\mathrm{P} \leq 0.10$ was retained. Covariates with a $\mathrm{P}$-value of $\geq 0.20$ were excluded from the model. Any covariate with $0.10<\mathrm{P}<0.20$ was further tested by removing it from the model; if removal resulted in a $15 \%$ or greater change in the hazard ratio for the exposure of interest, the covariate was retained in the model. The final models from the forward and backwards stepwise procedures were compared, and the model containing more covariates was reported, under the assumption that having more covariates in the model would make it more predictive.

\section{Results}

A total of 37 of the 209 participants reported an onset of rhinitis before ozone was first used in the bleachery and were thus excluded from the current analysis, the final total being 172 participants, with 104 bleachery workers and 68 paper mill workers. Twenty-seven (15.7\%) of the 172 participants reported the onset of noninfectious rhinitis after the introduction of ozone in 1992. There were no significant differences in age, atopy as an adult, or cigarette smoking by rhinitis status. However, those with noninfectious rhinitis were less likely to have had atopy as a child and less likely to be male (table 1).

Seventy-seven bleachery workers reported a history of any irritant gassing, with 45 in relation to ozone and 65 in relation to $\mathrm{ClO}_{2}$ or $\mathrm{SO}_{2}$. Crude incidence rates for noninfectious rhinitis were calculated for different

Table 1. Descriptive characteristics of the study population by rhinitis status.

\begin{tabular}{|c|c|c|c|c|c|c|c|}
\hline \multirow[t]{2}{*}{ Variables } & \multirow{2}{*}{$\begin{array}{c}\text { Men } \\
(\%)\end{array}$} & Age (years) & \multicolumn{2}{|c|}{ Atopy } & \multicolumn{3}{|c|}{ Cigarette smoking } \\
\hline & & Mean SD & $\begin{array}{c}\text { As a } \\
\text { child } \\
(\%)\end{array}$ & $\begin{array}{c}\text { As an } \\
\text { adult } \\
(\%)\end{array}$ & $\begin{array}{c}\text { Nev- } \\
\text { er } \\
(\%)\end{array}$ & $\begin{array}{l}\text { For- } \\
\text { mer } \\
(\%)\end{array}$ & $\begin{array}{l}\text { Cur- } \\
\text { rent } \\
(\%)\end{array}$ \\
\hline Rhinitis (N=27) & $81^{\text {a }}$ & 4112.4 & $4^{b}$ & 7 & 59 & 22 & 19 \\
\hline No rhinitis $(\mathrm{N}=145)$ & 92 & 429.75 & 10 & 8 & 52 & 33 & 15 \\
\hline
\end{tabular}

exposure groups, and the incidence rate ratios were calculated using the control mill workers as the reference category (table 2). The incidence rate ratio for all of the bleachery workers was elevated at 1.6 (95\% CI 0.7-3.6). When the bleachery workers were divided by whether they had ever reported respiratory symptoms after any gassings to $\mathrm{ClO}_{2}, \mathrm{SO}_{2}$, or ozone, the two groups had virtually the same rate ratio for noninfectious rhinitis. However, the bleachery workers who reported ozone gassings had a rate ratio of 2.1 [95\% confidence interval (95\%CI) 0.9-5.3] for noninfectious rhinitis, while the bleachery workers without reported ozone gassings had a rate ratio of only 1.1 (95\% CI 0.4-3.2) for noninfectious rhinitis.

Regression models confirmed the trends observed in the crude data. With control for gender, workers who reported symptoms after exposure to any of the three irritant gases had minimal risk of noninfectious rhinitis relative to the paper mill workers (hazard ratio 1.2, $95 \%$ CI 0.5-3.1) (data not shown). In contrast, bleachery workers who reported ozone gassings had an increased risk of noninfectious rhinitis (hazard ratio 3.4, 95\% CI 1.3-8.7), while those who reported no ozone gassings had a hazard ratio of 0.9 (table 3 ).

\section{Discussion}

This study found that bleachery workers who reported ozone gassings in the pulp mills were at increased risk for noninfectious rhinitis when compared with the

Table 2. Crude incidence and incidence rate ratios for rhinitis by gassing status. $(95 \% \mathrm{Cl}=95 \%$ confidence interval)

\begin{tabular}{lrrrrrr}
\hline Variable & $\mathrm{N}$ & $\begin{array}{c}\text { Cases } \\
\text { of } \\
\text { rhinitis } \\
(\mathrm{N})\end{array}$ & \multicolumn{5}{c}{$\begin{array}{c}\text { Person- } \\
\text { years }\end{array}$} & $\begin{array}{c}\text { Incidence } \\
\text { per1000 } \\
\text { person- } \\
\text { years }\end{array}$ & Ratio & $95 \% \mathrm{Cl}$ \\
\hline Paper Mill & 68 & 8 & 386 & 21 & 1.0 & reference \\
Bleachery & 104 & 19 & 578 & 33 & 1.6 & $0.7-3.6$ \\
Any gassings & 77 & 14 & 421 & 33 & 1.6 & $0.7-3.8$ \\
No gassings & 27 & 5 & 157 & 32 & 1.5 & $0.5-4.7$ \\
Ozone gassings & 45 & 11 & 248 & 44 & 2.1 & $0.9-5.3$ \\
No ozone gassings & 59 & 8 & 330 & 24 & 1.1 & $0.4-3.2$ \\
\hline Total & 172 & 27 & 964 & 28 & - & $\cdot$ \\
\hline
\end{tabular}

Table 3. Regression model for rhinitis, comparing those with ozone gassings to the paper mill workers without oxone gassings. (95\% Cl $=95 \%$ confidence interval)

\begin{tabular}{lcc}
\hline Variable & Hazard ratio & $95 \% \mathrm{Cl}$ \\
\hline Gender (men versus women) & 0.4 & $0.2-1.1$ \\
Bleachery workers without ozone gassings & 0.9 & $0.3-2.4$ \\
Bleachery workers with ozone gassings & 3.4 & $1.3-8.7$ \\
\hline
\end{tabular}


paper mill workers with no exposure to ozone. Although the association between occupational exposure to ozone and noninfectious rhinitis is not well documented in the literature, it is known that acute ozone exposure elicits inflammation in both the nasal and distal airways (30, 31 ). While another study found increased risk for noninfectious rhinitis among chlorine-exposed workers (21), we found bleachery workers who reported exposure to any gas $\left(\mathrm{ClO}_{2}, \mathrm{SO}_{2}\right.$, or ozone $)$ to have no increased risk for noninfectious rhinitis as a group.

There is no general agreement about the definition of rhinitis for use in epidemiologic studies. We used a combination of self-reported symptoms such as nasal blockage, sneezing, or runny nose, which has also been proposed by others $(15,32-34)$. Standardized postal questionnaires have been compared with face-to-face interviews using this question, and, on the assumption that the interview responses reflected the truth, the specificity was $91 \%$ and the sensitivity was $96 \%$ (13).

The use of questionnaire responses to determine exposure and outcome probably resulted in some imprecision and misclassification. All self-reported gassings were considered to have had approximately the same level of exposure, but it is likely that there was heterogeneity for the actual exposures within the gassing exposure category. We may have missed reports of some high-exposure events that did not result in symptoms, and we may have included some relatively low-exposure events that were associated with symptoms. In a study of acute chlorine gassings among pulp mill workers, Salisbury et al (35) found that a self-reported history of gassings was not as strong a predictor of decrements in pulmonary function and the frequency of respiratory symptoms as a first-aid report of gassing incidents. Since we used self-reports of gassing events rather than more objective measures, we may have underestimated the risk of noninfectious rhinitis in this study population. Finally, persons with ongoing nasal problems may have been more prone to give an affirmative answer to the rhinitis question than those whose symptoms had resolved before the questionnaire was administered.

Studies based on the results of questionnaires are subject to recall bias, especially when the questionnaire is used for assessing both exposure and outcome. In our study, for example, the participants with noninfectious rhinitis may have been more likely to report gassings, especially if gassings had been discussed in association with rhinitis. If this bias had occurred, we would have expected to see elevated risks for all types of gassings. Since ozone gassings, but not gassings due to $\mathrm{ClO}_{2}$ or $\mathrm{SO}_{2}$, were associated with rhinitis, it is not likely that exposure was overreported by those with symptoms.

We have based our analysis on comparisons of incidence rates. Epidemiologic studies of incidence rates of noninfectious rhinitis in adults are sparse. Broder et al
(36) reported an incidence of about $5 \%$ over a period of 4 years in the general population, which is equivalent to approximately 12 per 1000 person-years. Brisman \& Järvholm (33) mailed a questionnaire to a random population sample and calculated an incidence rate of 9.2 per 1000 person-years for males and 12.5 per 1000 person-years for females. The incidence rate of our control group was 21 per 1000 person-years, which is higher than the aforementioned figures based on the general population. However, the control group in our study was also exposed to paper dust, which increases the risk of noninfectious rhinitis (37). This increase in the risk of noninfectious rhinitis in our control group may mean that our hazard ratios for rhinitis among the bleachery workers could be underestimates of the true relative risk associated with ozone gassings.

In conclusion, our study shows that acute exposure to high levels of ozone may increase the risk of noninfectious rhinitis. These data further support the belief that occupational exposure to irritants in the work environment can induce nasal disease, and peak exposures should be prevented.

\section{Acknowledgments}

Funding support was received from the United States Centers of Disease Control, National Institute for Occupational Safety and Health, and the Swedish Council for Worklife Research.

\section{Disclaimer}

Mention of the name of any company or product does not constitute endorsement by the National Institute for Occupational Safety and Health.

\section{References}

1. Torén, K, Blanc PD. The history of pulp and paper bleaching: respiratory-health effects. Lancet 1997;349:1316-8.

2. Kennedy SM, Enarson DA, Janssen RG, Chan-Yeung M. Lung health consequences of reported accidental chlorine gas exposures among pulpmill workers. Am Rev Respir Dis 1991;143:74-9.

3. Henneberger PK, Ferris BG Jr, Sheehe PR. Accidental gassing incidents and the pulmonary function of pulp mill workers. Am Rev Respir Dis 1993;148:63-7.

4. Olin A-C, Granung G, Hagberg S, Adriansson M, Brisman J, Dalander O, et al. Respiratory health among bleachery workers exposed to ozone and chlorine dioxide. Scand J Work Environ Health 2002;28:117-23. 
5. Olin A-C, Ljungkvist G, Bake B, Hagberg S, Henriksson L, Torén K. Exhaled nitric oxide among pulpmill workers reporting gassing incidents involving ozone and chlorine dioxide. Eur Respir J 1999;14:828-31.

6. Greer JR, Abbey DE, Burchette RJ. Asthma related to occupational and ambient air pollutants in nonsmokers. J Occup Med 1993;35:909-15.

7. Abbey DE, Peterson F, Mills PK, Beeson WL. Long-term ambient concentrations of total suspended particulates, ozone, and sulfur dioxide and respiratory symptoms in a nonsmoking population. Arch Environ Health 1993;48:33-46.

8. Tolbert PE, Mulholland JA, MacIntosh DL, Xu F, Daniels D, Devine OJ, et al. Air quality and pediatric emergency room visits for asthma in Atlanta, Georgia. Am J Epidemiol 2000;151:798-810.

9. Friedman MS, Powell KE, Hutwagner L, Graham LM, Teague WG. Impact of changes in transportation and commuting behaviors during the 1996 Summer Olympic Games in Atlanta on air quality and childhood asthma. JAMA 2001;285:897905.

10. Middleton E. Chronic rhinitis in adults. J Allergy Clin Immunol 1988;81:971-5.

11. Bush RK, Wood RA, Eggleston PA. Laboratory animal allergy. J Allergy Clin Immunol 1998;102:99-112.

12. International Rhinitis Management Working Group. International consensus report on the diagnosis and management of rhinitis. Allergy 1994;49:1-34.

13. Sibbald B, Rink E. Epidemiology of seasonal and perennial rhinitis: clinical presentation and medical history. Thorax 1991;46:895-901.

14. Asher MI, Keil U, Anderson HR, Beasley R, Crane J, Martinez F. International study of asthma and allergies in childhood (ISAAC): rationale and methods. Eur Respir J 1995;8:48391.

15. Charpin D, Sibbald B, Weeke E, Wuthrich B. Epidemiologic identification of allergic rhinitis. Allergy 1996;51:293-8.

16. Bousquet J, Bullinger M, Fayol C, Marquis P, Valentin B, Burtin B. Assessment of quality of life in patients with perennial rhinitis with the French version of the SF-36 health status questionnaire. J Allergy Clin Immunol 1994;94:182-8.

17. Guerra S, Sherrill DL, Martinez FD, Barbee RA. Rhinitis as an independent risk factor for adult-onset asthma. J Allergy Clin Immunol 2002;109:419-25.

18. Plaschke PP, Janson C, Norrman E, Björnsson E, Ellbjär S, Järvholm B. Onset and remission of allergic rhinitis and asthma and the relationship with atopic sensitization and smoking. Am J Respir Crit Care Med 2000;162:920-4.

19. Leynaert B, Bousquet J, Neukirch C, Liard R, Neukirch F. Perennial rhinitis: an independent risk factor for asthma in nonatopic subjects. J Allergy Clin Immunol 1999;104:301-4.

20. Siracusa A, Desrosiers M, Marabini A. Epidemiology of occupational rhinitis: prevalence, aetiology, and determinants. Clin Exp Allergy 2000;30:1519-34.

21. Leroyer C, Malo J-C, Girard D, Dufour J-G, Gautrin D. Chronic rhinitis in workers at risk of reactive airways dys- function syndrome due to exposure to chlorine. Occup Environ Med 1999;56:334-8.

22. Hajat S, Haines A, Atkinson RW, Bremner SA, Anderson HR, Emberlin J. Association between air pollution and daily consultations with general practitioners for allergic rhinitis in London, United Kingdom. Am J Epidemiol 2001;153:70414.

23. Peden DB. Effect of pollutants in rhinitis. Curr Allergy Asthma Rep 2001;1:242-6.

24. Torén K, Hagberg S, Westberg H. Health effects of working in pulp and paper mills: exposure, obstructive airways diseases, hypersensitivity reactions, and cardiovascular diseases. Am J Ind Med 1996;29:111-22.

25. Hellgren J, Torén K, Balder B, Palmqvist M, Löwhagen O, Karlsson G. Increased nasal mucosal swelling in subjects with asthma. Clin Exp Allergy 2002;32:64-9.

26. Torén K, Olin A-C, Hellgren J, Hermansson BA. Rhinitis increases the risk for adult-onset asthma. Respir Med 2002;96:635-41.

27. Matricardi PM., Nisini R, Pizzolo JG, d'Amelio R. The use of Phadiatop ${ }^{\circledR}$ in mass-screening programmes of inhalant allergies: advantages and limitations. Clin Exp Allergy 1990; 20:151-5.

28. SAS Institute. SAS/STAT user's guide, version 8. Cary (NC): SAS Institute; 1999.

29. Allison PD. Survival analysis using the SAS System: a practical guide. Cary (NC): SAS Institute; 1995.

30. Krishna MT, Mudway I, Kelly FJ, Frew AJ, Holgate ST. Ozone, airways, and allergic disease. Clin Exp Allergy 1995;25:1150-8.

31. Graham DE, Koren HS. Biomarkers of inflammation in ozoneexposed humans: comparison of the nasal and bronchoalveolar lavage. Am Rev Respir Dis 1990;142:152-6.

32. Ng TP, Tan WC. Epidemiology of allergic rhinitis and its associated risk factors in Singapore. Int $\mathrm{J}$ Epidemiol 1994;23:553-8.

33. Jessen M, Janzon L. Prevalence of non-allergic nasal complaints in an urban and a rural population in Sweden. Allergy 1989;44:582-7.

34. Brisman J, Järvholm B. Bakery work, atopy and the incidence of self-reported hay fever and rhinitis. Eur Respir J 1999;13:502-7.

35. Salisbury DA, Enarson DA, Chan-Yeung M, Kennedy SM. First-aid reports of acute chlorine gassing among pulpmill workers as predictors of lung health consequences. Am J Ind Med 1991;20:71-81.

36. Broder I, Higgins MW, Mathews KP, Keller JB. Epidemiology of asthma and allergic rhinitis in a total community, Tecumseh, Michigan. J Allergy Clin Immunol 1974;54:100-10.

37. Hellgren J, Lillienberg L, Jarlstedt J, Karlsson G, Torén K. A population-based study of non-infectious rhinitis in relation to occupational exposure, age, sex, and smoking. Am J Ind Med 2002;42:23-8.

Received for publication: 26 February 2004 